This article was downloaded by:[Narvaez, Darcia]

On: 13 March 2008

Access Details: [subscription number 791421834]

Publisher: Routledge

Informa Ltd Registered in England and Wales Registered Number: 1072954

Registered office: Mortimer House, 37-41 Mortimer Street, London W1T 3JH, UK

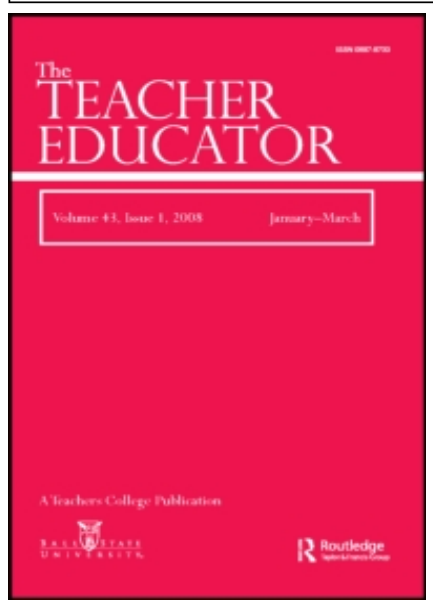

\title{
The Teacher Educator
}

Publication details, including instructions for authors and subscription information: http://www.informaworld.com/smpp/title content=t788175743

TEACHING MORAL CHARACTER: TWO ALTERNATIVES FOR TEACHER EDUCATION

Darcia Narvaez ${ }^{\text {a. }}$ Daniel K. Lapsley ${ }^{a}$

a Department of Psychology, University of Notre Dame,

Online Publication Date: 01 April 2008

To cite this Article: Narvaez, Darcia and Lapsley, Daniel K. (2008) 'TEACHING MORAL CHARACTER: TWO ALTERNATIVES FOR TEACHER EDUCATION', The Teacher Educator, 43:2, $156-172$

To link to this article: DOI: $10.1080 / 08878730701838983$

URL: http://dx.doi.org/10.1080/08878730701838983

\section{PLEASE SCROLL DOWN FOR ARTICLE}

Full terms and conditions of use: http://www.informaworld.com/terms-and-conditions-of-access.pdf

This article maybe used for research, teaching and private study purposes. Any substantial or systematic reproduction, re-distribution, re-selling, loan or sub-licensing, systematic supply or distribution in any form to anyone is expressly forbidden.

The publisher does not give any warranty express or implied or make any representation that the contents will be complete or accurate or up to date. The accuracy of any instructions, formulae and drug doses should be independently verified with primary sources. The publisher shall not be liable for any loss, actions, claims, proceedings, demand or costs or damages whatsoever or howsoever caused arising directly or indirectly in connection with or arising out of the use of this material. 
The Teacher Educator, 43:156-172, 2008 Copyright $(9)$ Taylor \& Francis Group, LLC ISSN: $0887-8730$ print/1938-8101 online DOI: $10.1080 / 08878730701838983$

\title{
OPEN FORUM
}

\section{TEACHING MORAL CHARACTER: TWO ALTERNATIVES FOR TEACHER EDUCATION}

\author{
DARCIA NARVAEZ and DANIEL K. LAPSLEY
}

Department of Psychology, University of Notre Dame

\begin{abstract}
Debating whether or not teachers should teach values addresses the wrong question. Education already is a values-infused enterprise. The larger question is how to train teachers for positive character formation. Two teacher education strategies are presented in this article. A "minimalist" strategy requires teacher educators to make explicit the hidden moral education curriculum and to reveal the inextricable linkage between best practice instruction and moral character outcomes. The "maximalist" approach requires preservice teachers to master a tool kit of pedagogical strategies that target moral character directly as a curricular goal. To this end, the Integrative Ethical Education model outlines five steps for moral character development: supportive climate, ethical skills, apprenticeship instruction, self-regulation, and adopting a developmental systems approach.
\end{abstract}

\section{Teaching Moral Character: Towards a Conceptual Framework for Teacher Education}

The importance of character education is an idea that is gaining momentum among politicians and educators. Over a dozen states have mandated character education, and hundreds of schools have incorporated it into their programming (e.g., Los Angeles Times, 2003). Moreover, in the last several years, three top education periodicals (Educational Leadership, Phi Delta Kappan, Journal

Address correspondence to Dr. Darcia Narvaez, Center for Ethical Education, 118 Haggar Hall, University of Notre Dame, Notre Dame, IN 46556, USA. E-mail: dnarvaez@nd.edu 
of Teacher Education) have stressed the importance of character, ethics, and spirituality in education. Despite all the increased interest in implementing character education among school districts, state legislatures, and academic researchers (CASEL Connections, 2005), it is a striking fact that few teacher education programs are intentionally and deliberately preparing preservice teachers for the task (Schwartz, in press).

The relative neglect of moral character education in the formal preservice teacher curriculum has at least two proximal causes. The first is the daunting surfeit of training objectives that already crowd the academic curriculum of teaching majors. When faced with the reality of finite credit hours available for teacher education versus the demands of NCATE accreditation and state licensing requirements, many teacher educators assume that the preservice curriculum leaves little room for training in character education. The second cause is the puzzling phenomenon whereby stakeholders-parents and school boardsexpect schools to address the character of students, but nobody wants to be caught teaching values. The fear in regard to supporting character education is that one might be asked, "Whose values are being taught?"

Yet values are embedded inextricably in school and classroom life (Campbell, 2003; Fenstermacher, 1990; Hansen, 1993; Tom, 1984). Teachers implicitly impart values when they select or exclude topics; when they insist on certain answers as being correct; when they encourage students to seek the truth of a matter; and when they establish classroom routines, form groups, enforce discipline, and encourage excellence. Teachers mold certain forms of social life within classrooms and influence students' experiences of community and school membership. Moral values saturate the daily life of classrooms (Bryk, 1988; Goodlad, 1992; Hansen, 1993; Strike, 1996). Character formation is intrinsic to classrooms and schools and is an inescapable part of the teacher's craft (Campbell, 2003; Hansen, 1993; Jackson, Boostrom, \& Hansen, 1993; Lapsley \& Narvaez, 2006).

The dilemma that teacher educators face, then, is whether it is acceptable to allow character education to remain part of a school's hidden curriculum or whether advocacy for the value commitments immanent to education and teaching should be transparent, intentional, and public. Our sympathy is with the 
latter option, but how do teacher educators equip preservice teachers with the skills to take up their task as moral educators? What would training for character and ethical development look like?

Two alternative approaches are presented here. The first approach views character education as immanent to best practice instruction. This approach argues that there is little need for specialized instruction in ethics or in the design of distinctly moral education curriculum. Rather, character development is an outcome of effective teaching. It is a precipitate of best practice instruction. Hence, in order to be assured that the moral formation of students will be in good hands, the teacher educator need only ensure that preservice teachers are prepared to be outstanding teachers.

The second view is that best practice teaching is necessary but not sufficient for effective moral formation of pupils. Perhaps at some point in the halcyon past it was sufficient, but in the present cultural milieu, children are often reared in toxic environments that pose special challenges for their moral and social development (Garbarino, 2004; Quart, 2003). As a result, teachers are called upon to offer a counterweight to the malformative elements permeating children's lives, a responsibility that calls for a more intentional and deliberate approach. This intentional strategy is committed to the view that students flourish in classroom communities and that children are best equipped to take on the challenges of development when they master the skill sets required for responsible membership in a democratic society (Guttman, 1987).

\section{Option 1: Best Practice Instruction is Sufficient for Moral Character Formation}

Effective teaching for moral character aligns with best practice instruction for academic achievement. The knowledge base that supports best practice instruction is coterminous with what is known to influence the moral formation of students. Making explicit this linkage should be a clear goal for teacher education. Preservice teachers should consider not only how instructional practice influences academic learning but also how it shapes 
student character development. As we will see, schooling and teacher practices that promote achievement overlap with practices that support student prosocial development (Sebring, 1995). Effective teaching promotes both academic and moral excellence (Solomon, Watson, \& Battistich, 2002). We will focus on two domains where best practice instruction pays dividends for moral character education: socioemotional skill development and caring classrooms and schools.

\section{Caring School Community}

Character formation begins with a caring relationship, first in the home and then at school. A caring relationship forms the bridge from adult to child through which mutual influence can occur (Greenspan \& Shanker, 2004). A child who is cared for will likely care for others and will engage as a citizen in the moral life of the community. The quality of early teacher-student relationships can have a strong influence on academic and social outcomes that persist through eighth grade (Hamre \& Pianta, 2001). In a study of middle-school students, Wentzel (2002) showed that teaching styles that conform to dimensions of effective parenting were a significant predictor of students' academic goals, interest in school, and mastery learning orientation (even after controlling for demographic factors such as gender, race, and students' control beliefs). In particular, teachers who had high expectations tended to have students who earned better grades but who also pursued prosocial goals, took responsibility, and showed a commitment to mastery learning. Conversely, teachers who were harshly critical and were perceived to be unfair had students who did not act responsibly with respect to classroom rules and academic goals.

Caring schools and classrooms provide multiple benefits for students. Caring school climates encourage social and emotional bonding and promote positive interpersonal experiences, providing the minimum grounding necessary for the formation of character (Schaps, Battistich, \& Solomon, 1997). Moreover, in schools with a strong indication of communal organization, less student misconduct is noted (Bryk \& Driscoll, 1988) and rates of drug use and delinquency are lower (Battistich \& Hom, 1997). Student 
attachment or bonding to school improves school motivation (Goodenow, 1993) and discourages delinquency (Welsh, Greene, \& Jenkins, 1999) and victimization of teachers and students (Gottfredson \& Gottfredson, 1985). Schools characterized by a strong sense of community report decreased discipline problems and less drug use, delinquency, and bullying; conversely, they also report higher attendance and improvements in academic performance (see Lapsley \& Narvaez, 2006, for a review). Research by the Developmental Studies Center provides compelling evidence that a sense of classroom and school community is positively related to self-reported concern for others, conflict resolution skills, altruistic behavior, intrinsic prosocial motivation, and trust in and respect for others (Battistich, Solomon, Watson, \& Schaps, 1997; Schaps, Battistich, \& Solomon, 1997). In conclusion, caring classroom environments are associated with greater academic achievement and prosocial behavior (Zins, Weissberg, Wang, \& Walberg, 2004).

We noted earlier that effective teachers have the qualities of good parents. Indeed, teachers with positive attitudes about students are more likely to foster student achievement and ethical behavior (Haberman, 1995). Such teachers adopt the attitude that they will do all they can to help students meet basic needs, such as autonomy, belonging, and competence (Deci \& Ryan, 1985) and a sense of purpose, understanding, and trust (Fiske, 2004). When a student's basic needs are unmet, the focus on learning can be supplanted by misbehavior and disengagement. The way to best meet these basic needs is in a group setting that provides "a focus for identification and commitment" (Battistich et al., 1997, p. 138) and in which students can "participate actively in a cohesive, caring group with a shared purpose; that is, a community" (ibid.). As Watson (2003) pointed out, teachers can learn to pay attention to student needs throughout the day and coach difficult students on how to best meet their own needs. Again, the result is students who are more academically focused and higher achieving, as well as prosocial citizens (Wahlberg, Zins, \& Weissberg, 2004).

Building a caring classroom community takes some skill on the part of the teacher. According to Solomon et al. (2002), caring school and classroom communities have the following characteristics. First, the teacher models respectful behavior and 
is warm, accepting, and supportive of students. Second, students have influence on important classroom decisions. Specifically, students have the autonomy to make important choices in the classroom related to their own self-development and are encouraged to participate in activities like rule making. Third, students have opportunities to interact, collaborate, and discuss important issues with one another. Fourth, students practice social skills and have opportunities to help others.

In summary, teachers need content knowledge about the links among caring classrooms, achievement, and prosocial character. Teachers need the pedagogical skills to foster a caring classroom, as well as the disposition to be committed to providing caring climates as a teaching practice. A second best practice is described next—social and emotional skill development.

\section{Social and Emotional Skills}

Social and emotional skills are crucial to school success. Recent research suggests that emotional intelligence has more bearing on life and school outcomes than does academic intelligence (Zins et al., 2004). As Goleman (2004) stated, "Social and emotional learning programs pave the way for better academic learning. They teach children social and emotional skills that are intimately linked with cognitive development" (p. viii). Social and emotional skills facilitate everyday life, affecting relationships and school achievement-skills in communication, conflict resolution, decision making, and cooperation (Catalano, Haggerty, Oesterle, Fleming, \& Hawkins, 2004). A substantial body of literature indicates that programs that address social and emotional competencies are effective in preventing problem behaviors (Durlak \& Wells, 1997; Wilson, Gottfredson, \& Najaka, 2001), including drug use (Tobler et al., 2000) and violence (Greenberg \& Kusche, 1998; Greenberg, Kusche, Cook, \& Quamma, 1995). Social and emotional learning is also a strong predictor of academic outcomes (Elias et al., 2003; Shriver \& Weissberg, 2005). One study demonstrated, for example, that indices of social competence were better predictors of eighth-grade academic achievement than was third-grade academic achievement (Caprara, Barbanelli, Pastorelli, Bandura, \& Zimbardo, 2000). 


\section{Implications}

Given the tight connection between best practice instruction for academic expertise and for moral development, teachers are unwittingly engaged in character education when they structure lessons and organize classrooms in ways that optimally support student learning. The implication for teacher education is straightforward: adopt a best practice approach to instruction for character education. Preservice reflective practice could address the pedagogical strategies that are correlated with student academic achievement, making apparent their implications for moral character education. Moreover, teacher educators can help preservice teachers appreciate how and where moral values permeate classrooms and schools and help them further understand that embedding values in the blanket of instructional best practice does not relieve them of their moral duty as educators or evade the fundamentally moral purpose of education.

\section{Option 2: Best Practice is Necessary but not Sufficient}

The first option discussed in this article does not require significant revision of the standard teacher education curriculum. It requires no specialized curriculum and no toolbox of specialized instructional strategies. This option requires only reflective intentionality about the dual implications of best practice instruction-that it advances the cause of both academic achievement and of moral character formation. The second view that will be discussed agrees that instructional best practice is necessarybut it is not sufficient to equip students with the skills necessary to negotiate the demands of modern life. No guarantee exists that students will experience positive moral formation outside of school, let alone experience guidance broad or explicit enough to prepare them to be morally competent adults. Often in poor urban neighborhoods, for example, few positive role models are found (Jargowsky \& Sawhill, 2006), and young people receive very little coaching for moral citizenship. The task of preparing morally adept individuals requires a more intentional programmatic instructional focus (Lapsley \& Narvaez, 2006). The frame- 
work presented next addresses specifically the issue of what and how to teach for positive character formation. ${ }^{1}$

The Integrative Ethical Education (IEE) model blends several key findings from empirical science to provide a step-bystep framework for cultivating moral character (Narvaez, 2006; 2007). The steps may be taken one at a time or all at once. Within a context saturated with high expectations for behavior and achievement, educators deliberatively build the following within the classroom and school:

Step 1: Foster a supportive climate for moral behavior and high achievement

Step 2: Cultivate ethical skills

Step 3: Use an apprenticeship approach to instruction (noviceto-expert guided practice)

Step 4: Nurture self-regulation skills

Step 5: Build support structures with the community

The first step has been described as best practice previously in this article, under Caring School Community, and so will not be addressed further. The second and third steps, discussed together, are rooted in an expansion of Rest's Four Component Model (Narvaez \& Rest, 1995; Rest, 1983) and expertise development. The Four Component Model describes the psychological skills or processes that a person uses in order to complete a moral behavior: ethical sensitivity, ethical judgment, ethical focus, and ethical action. Ethical sensitivity refers to perceiving the moral issue cognitively and emotionally and identifying courses of action, affected parties, and reactions. Ethical judgment entails applying a code of ethics to make a decision about the most moral choice. Ethical focus involves prioritizing the moral choice, and ethical

\footnotetext{
${ }^{1}$ The Integrative Ethical Education Model was initially developed in collaboration with Minnesota educators during the Community Voices and Character Education project (Narvaez, Bock, Endicott, \& Lies, 2004). From 1998-2002, the Minnesota Department of Education (formerly the Department of Children, Families, and Learning) implemented the Community Voices and Character Education Project (CVCE) with funds from the U.S. Department of Education (USDE OERI Grant \# R215V980001). Project materials may be obtained from the first author or at the Collaborative for Ethical Education, http://cee.nd.edu. The IEE model was subsequently extended, based on further research (Narvaez, 2006).
} 
action is the ability and strength to carry through on the moral choice.

Current understanding of knowledge acquisition adopts the novice-to-expert learning paradigm (Bransford, Brown, \& Cocking, 1999). Sternberg (1998) contends that abilities are developing expertise. According to this approach, individuals build their knowledge over time during the course of experiences related to a particular knowledge domain, thereby increasing in expertise. Experts have large, rich, organized networks of concepts (schemas) containing a great deal of declarative, procedural, and conditional knowledge about the domain. Experts are more efficient at solving problems in the domain, monitoring their progress, and deriving workable solutions.

In turn, moral experts apply skills and demonstrate holistic orientations in one or more of the processes outlined in the Four Component Model. Experts in ethical sensitivity are better at quickly and accurately reading a moral situation and determining what role they might play. They consider others' perspectives and control their own personal bias in an effort to be morally responsive to others. Experts in ethical judgment have many tools for solving complex moral problems. They reason about duty and consequences, responsibility, and religious codes. Experts in ethical focus cultivate moral self-regulation that leads them to prioritize ethical goals. They foster an ethical identity that leads them to align the self with moral commitments. Experts in ethical action know how to keep their eye on the prize, enabling them to stay on task and take the necessary steps to complete the ethical job. Thus, moral character entails skills and attitudes that can be honed to high levels of expertise.

A key task of character education, then, is to cultivate component skills to higher levels of expertise. Each of the four components is a toolkit of subskills. Table 1 lists the skills that were identified over the course of the Minnesota Community Voices and Character Education project, a federally funded collaborative project conducted with middle-school educators (Anderson, Narvaez, Bock, Endicott, \& Lies, 2004; Narvaez, Bock, \& Endicott, 2003; Narvaez Bock, Endicott, \& Lies, 2004). These skills were identified as those that could be incorporated into standardsdriven instruction, as well as into other aspects of schooling such as homeroom or advisory and school-wide projects. Participating 
TABLE 1 The Four Processes and Related Skill Categories of the Integrative Ethical Education Model

\begin{tabular}{|c|c|}
\hline Ethical Sensitivity & Ethical Judgment \\
\hline Understand Emotional Expression & Understanding Ethical Problems \\
\hline Take the Perspectives of Others & $\begin{array}{l}\text { Using Codes and Identifying } \\
\text { Judgment Criteria }\end{array}$ \\
\hline Connecting to Others & Reasoning Generally \\
\hline Responding to Diversity & Reasoning Ethically \\
\hline Controlling Social Bias & Understand Consequences \\
\hline Interpreting Situations & Reflect on the Process and Outcome \\
\hline Communicating Effectively & Coping and Resiliency \\
\hline Ethical Focus (Motivation) & Ethical Action \\
\hline Respecting Others & Resolving Conflicts and Problems \\
\hline Develop Conscience & Assert Respectfully \\
\hline Act Responsibly & Taking Initiative as a Leader \\
\hline Be Community Member & Implementing Decisions \\
\hline Finding Meaning in Life & Cultivate Courage \\
\hline Valuing Traditions and Institutions & Persevering \\
\hline $\begin{array}{l}\text { Developing Ethical Identity and } \\
\text { Integrity }\end{array}$ & Work Hard \\
\hline
\end{tabular}

educators used a novice-to-expert approach in developing student skills.

Teaching for expertise involves direct instruction through role modeling, expert demonstration, and thinking aloud (Sternberg, 1998), focusing attention on ethical aspects of situations and expressing the importance of ethical behavior. It also requires indirect instruction through immersion in environments where skills and procedures can be practiced extensively (Hogarth, 2001). Based on current research (e.g., Marshall, 1999), the Minnesota Community Voices and Character Education project identified four levels of instruction, to be selected according to student level of understanding. In Level 1: Immersion in Examples and Opportunities, the student sees prototypes of the behavior to be learned and begins to attend to the big picture, learning to recognize basic patterns. The teacher plunges students into multiple, engaging activities. Students learn to recognize broad patterns in the domain (identification knowledge). They develop gradual awareness and recognition of elements in 
the domain. In Level 2: Attention to Facts and Skills, the student learns to focus on detail and prototypical examples, building a knowledge base. The teacher focuses the student's attention on the elemental concepts in the domain in order to build elaboration knowledge. Skills are gradually acquired through motivated, focused attention. In Level 3: Practice Procedures, the student learns to set goals, plan steps of problem solving, and practice skills. The teacher coaches the student and allows the student to try out many skills and ideas throughout the domain in order to build an understanding of how these relate and how best to solve problems in the domain (planning knowledge). Skills are developed through practice and exploration. In Level 4: Integrate Knowledge and Procedures, the student executes plans and solves problems. The student finds numerous mentors or seeks out information to continue building concepts and skills. A gradual systematic integration and application of skills occurs across many situations. The student learns how to take the steps in solving complex domain problems (execution knowledge). This set of novice-to-expert levels leads students to the fourth step, self-regulation.

The fourth step in the IEE model is self-regulation. Students must learn to use their skills independently. Individuals can be coached not only in skills and expertise but also in domainspecific self-efficacy and self-regulation (Zimmerman, Bonner, \& Kovach, 2002). The most successful students learn to monitor the effectiveness of the strategies they use to solve problems and, when necessary, alter their strategies for success (Anderson, 1989). According to Zimmerman (2000), self-regulation is acquired in stages; these resemble the processes of scaffolded learning in the zone of proximal development. First, the child vicariously induces the skill by observing a model. Second, the child imitates the model with assistance. Third, the child independently displays the skill under structured conditions. Finally, the child is able to use the skill across changing situations and demands.

Teachers should understand their roles as facilitators of student self-development. Able learners have good self-regulatory skills for learning (Zimmerman, 1998). Teachers have a chance to help students develop the attitudes and skills necessary for the journey toward expertise. This is true for moral character as 
well. As in any domain, moral character skills must be practiced in order to be developed. Teachers must be oriented to providing good practice opportunities for students. For example, if students do not get practice in helping others, they are less likely to do it independently when the occasion arises (Youniss \& Yates, 1997). With adult coaching, each student can monitor ethical skill development and hone a particular set of expert skills. Once developed, virtues must be maintained through the selection of appropriate friends and environments (Aristotle, 1988). Virtuous individuals are autonomous enough to monitor their behavior and choices.

A developmental systems approach (Lerner, Dowling, \& Anderson, 2003) can serve as the broad conceptual framework for step 5. The desire to strengthen connections among home, school, and community is supported by ecological perspectives on human development. Children whose developmental ecology is characterized by a richly connected mesosystem experience adaptational advantages (Bronfenbrenner, 1979). The work of the Search Institute on developmental assets is one substantiation of this general approach (Benson, Scales, Leffert, \& Roehlkepartain, 1999; Scales \& Leffert, 1999). Developmental assets are those features of a developmental system that promote positive outcomes. External assets refer to the positive developmental experiences that result from the network of relationships that youth have with adults in family, school, and community. Internal assets refer to endogenous skills, dispositions, and interests that emerge over the course of education and development. Benson, Scales, Leffert, and Blyth (1998) reported dramatic differences between the percentage of youth with low (0-10) assets who engage in risk behavior and those with high (31-40) assets. Benson et al. also reported a strong connection between asset levels and thriving factors. Although youth from at-risk backgrounds benefit more from asset-building approaches, wealthy neighborhoods are often lacking in many asset-building features. Educators should work hand-in-hand with parents and community leaders to ensure that asset and ethical skill building occurs across every context in which students participate.

Finally, all five steps of the IEE model should occur in a setting where the educators have high expectations for behavior and achievement. This is especially key for disadvantaged students 
who do not achieve under caring and supportive conditions alone (Zins et al., 2004). The five steps work in concert to bring about the greatest change for achievement and character.

In summary, the IEE framework provides a functional view of what steps a teacher can take in deliberately fostering moral character. First, teacher educators point out the importance of establishing a respectful and caring relationship with students, helping preservice teachers understand and practice different ways to do this. This is accompanied by helping preservice teachers learn how to establish a supportive classroom climate, which is important for achievement and ethical character development. Second, teacher educators help their students identify the ethical skills that support academic and social success, guiding them to understand ways these can be taught during the school day in academic and non-academic lessons. Third, preservice teachers learn how to cultivate expertise in students not only in the preservice teacher's academic discipline, but also for an ethical social life. Fourth, in subject matter and in social life, preservice teachers develop techniques to help their students foster selfregulation and self-efficacy. Fifth, as part of their professional dispositions, educators can learn to work with a developmental systems approach in mind, linking to parents and community members for maximal positive development of students. Thus, IEE provides teacher educators with a potential unit plan for equipping preservice education majors with the skills necessary to take on their moral education responsibilities with intentional transparency.

\section{Conclusion}

Student moral development is both implicit and inevitable in standard educational practice. The challenge facing teachers and teacher educators is whether to allow moral formation to occur opportunistically-letting students learn what they will, for good or bad, come what may-or to foster an intentional, transparent, and deliberative approach that seriously considers the moral dimensions of teaching and schooling. Two teacher education strategies were proposed herein. The minimalist strategy requires teacher educators to make explicit the hidden moral education curriculum and to encourage preservice teachers to see the moral 
character outcomes that are immanent to best practice instruction. The maximalist strategy requires that preservice teachers learn a toolkit of pedagogical skills that targets moral character education as an explicit curricular goal. It is important to know that when teachers are intentional and wise in praxis, they provide students with a deliberative, positive influence on their individual and group characters.

\section{References}

Anderson, L. M. (1989). Learners and learning. In M. C. Reynolds (Ed.), Knowledge base for the beginning teacher (pp. 85-99). Oxford: Pergamon Press.

Anderson, C., Narvaez, D., Bock, T., Endicott, L., \& Lies, J. (2004). Minnesota community voices and character education: Final report and evaluation. Roseville: Minnesota Department of Children, Families and Learning.

Aristotle (1988). Nicomachean ethics (W. D. Ross, Trans.). London: Oxford.

Battistich, V., \& Hom, A. (1997). The relationship between students' sense of their school as a community and their involvement in problem behavior. American Journal of Public Health, 87, 1997-2001.

Battistich, V., Solomon, D., Watson, M., \& Schaps, E. (1997). Caring school communities. Educational Psychologist, 32, 137-151.

Benson, P. L., Leffert, N., Scales, P. C., \& Blyth, D. A. (1998). Beyond the "village" rhetoric: Creating healthy communities for children and adolescents. Applied Developmental Science, 2, 138-159.

Benson, P. L., Scales, P. C., Leffert, N., \& Roehlkepartain, E. C. (1999). A fragile foundation: The state of developmental assets among American youth. Minneapolis, MN: Search Institute.

Bransford, J. D., Brown, A. L., \& Cocking, R. R. (Eds.). (1999). How people learn: Brain, mind, experience, and school. Washington, DC: National Academy Press.

Bronfenbrenner, U. (1979). The ecology of human development. Cambridge, MA: Harvard University Press.

Bryk, A. S. (1988). Musings on the moral life of schools. American Journal of Education, 96(2), 256-290.

Bryk, A. S., \& Driscoll, M. (1988). The school as community: Shaping forces and consequences for students and teachers. Madison: University of Wisconsin, National Center for Effective Secondary Schools.

Bryk, A., \& Schneider, B. (2002). Trust in schools: A core resource for improvement. New York: Russell Sage.

Campbell, E. (2003). The ethical teacher. Maidenhead, Berkshire, England: Open University Press.

Caprara, G. V., Barbanelli, C., Pastorelli, C., Bandura, A., \& Zimbardo, P. G. (2000). Prosocial foundations of children's academic achievement. Psychological Science, 11, 302-306.

CASEL Connections. (August, 2005). University of Illinois-Chicago: Collaborative for Academic, Social and Emotional Learning. 
Deci, E., \& Ryan, R. (1985). Intrinsic motivation and self-determination in human behavior. New York: Academic Press.

Durlak, J. A., \& Wells, A. M. (1997). Primary prevention mental health programs for children and adolescents: A meta-analytic review. American Journal of Community Psychology, 25, 115-152.

Elias, M. J., Zins, J. E., Graczyk, P. A., \& Weissberg, R. P. (2003). Implementation, sustainability, and scaling up of social-emotional and academic innovations in public schools. School Psychology Review, 32, 303-319.

Fiske, S. (2004). Social beings. New York: Wiley.

Gabarino, J. (1999). Raising children in a socially toxic environment. San Francisco: Jossey-Bass.

Goleman, D. (2004). Foreword. In J. E. Zins, R. P. Weissberg, M. C. Wang, \& H. J. Walberg (Eds.), Building academic success on social and emotional learning (pp. vii-viii). New York: Teachers College Press.

Goodenow, C. (1993). The psychological sense of school membership among adolescents: Scale development and educational correlates. Psychology in the Schools, 30, 79-90.

Goodlad, J. (1992). The moral dimensions of schooling and teacher education. Journal of Moral Education, 21(2), 87-98.

Gottfredson, G., \& Gottfredson, D. (1985). Victimization in schools. New York: Plenum.

Greenberg, M. T., \& Kusche, C. A. (1998). Promoting alternative thinking strategies: Blueprint for violence prevention. Book 10. Institute for the Behavioral Sciences, University of Colorado.

Greenberg, M. T., Kusche, C. A., Cook, E. T., \& Quamma, J. P. (1995) Promoting emotional competence in school-aged children: The effects of the PATHS curriculum. Development and Psychopathology, 7, 117-136.

Greenspan, S. I., \& Shanker, S. G. (2004). The first idea: How symbols, language and intelligence evolved from our primate ancestors to modern humans. Cambridge, MA: Da Capo Press.

Guttman, A. (1987). Democratic education. Princeton, NJ: Princeton University Press.

Haberman, M. (1995). Star teachers of children in poverty. West Lafayette, IN: Kappa Delta Pi.

Hamre, B. K., \& Pianta, R. C. (2001). Early teacher-child relationships and the trajectory of children's school outcomes through eighth grade. Child Development, 72, 625-638.

Hansen, D. T. (1993). From role to person: The moral layeredness of classroom teaching. American Educational Research Journal, 30, 651-674.

Hansen, D. T. (1995). Teaching and the moral life of classrooms. Journal for a Just Eै Caring Education, 2, 59-74.

Hansen, D. T. (2001). Teaching as a moral activity. In V. Richardson (Ed.), Handbook of research on teaching (4th ed., pp. 826-857). Washington, DC: AERA.

Hogarth, R. M. (2001). Educating intuition. Chicago: University of Chicago Press.

Jackson, P., Boostrom, R. E., \& Hansen, D. T. (1993). The moral life of schools. San Francisco: Jossey-Bass. 
Jargowsky, P. A., \& Sawhill, I. (January, 2006). The decline of the underclass, CCF Brief \#36. Washington, DC: Center for Children and Families at The Brookings Institution.

Lapsley, D. K., \& Narvaez, D. (2006). Character education. In Vol. 4 (A. Renninger \& I. Siegel, volume eds.) (W. Damon \& R. Lerner, Series Eds.), Handbook of child psychology (pp. 248-296). New York: Wiley.

Lerner, R. M., Dowling, E. M., \& Anderson, P. M. (2003). Positive youth development: Thriving as a basis of personhood and civil society. Applied Developmental Science, 7, 172-180.

Linn, S. (2004). Consuming kids: The hostile takeover of childhood. New York: New Press.

Los Angeles Times (November 5, 2003). More schools make ethics part of curriculum.

Marshall, S. (1999). Schemas in problem solving. Cambridge, England: Cambridge University Press.

Narvaez, D. (2006). Integrative ethical education. In M. Killen \& J. Smetana (Eds.), Handbook of moral development (pp. 703-733). Mahwah, NJ: Erlbaum.

Narvaez, D. (2007). How cognitive and neurobiological sciences inform values education for creatures like us. In D. Aspin \& J. Chapman (Eds.), Values education and lifelong learning: Philosophy, policy, practices (pp. 127-159). Springer Press International.

Narvaez, D., Bock, T., \& Endicott, L. (2003). Who should I become? Citizenship, goodness, human flourishing, and ethical expertise. In W. Veugelers \& F. K. Oser (Eds.), Teaching in moral and democratic education (pp. 43-63). Bern, Switzerland: Peter Lang Publishers.

Narvaez, D., Bock, T., Endicott, L., \& Lies, J. (2004). Minnesota's Community Voices and Character Education Project.Journal of Research in Character Education, 2, 89-112.

Narvaez, D., \& Rest, J. (1995). The four components of acting morally. In W. Kurtines \& J. Gewirtz (Eds.), Moral behavior and moral development: An introduction (pp. 385-400). New York: McGraw-Hill.

Quart, A. (2003). Branded: The buying and selling of teenagers. New York: Basic.

Rest, J. (1983). Morality. In P. Mussen (Series Ed.) \& J. Flavell \& E. Markham (Vol. Eds.), Manual of child psychology: Vol. 3. Cognitive development (pp. 556629). New York: Wiley.

Scales, P. C., \& Leffert, N. (1999). Developmental assets: A synthesis of the scientific research on adolescent development. Minneapolis, MN: Search Institute.

Schaps, E., Battistich, V., \& Solomon, D. (1997). School as a caring community: A key to character education. In A. Molnar (Ed.), The construction of children's character (pp. 127-139). Chicago: University of Chicago Press.

Schwartz, M. (2008). Teacher preparation for character development. In L. Nucci \& D. Narvaez (Eds.), Handbook of moral and character education (pp. 583-600). Mahwah, NJ: Erlbaum.

Sebring, P., Bryk, A., \& Easton, J. (1995). Charting reform: Chicago teachers take stock. Chicago: The Consortium on Chicago Schools Research.

Sebring, P. B., \& Bryk, A. S. (1996). Student centered learning climate. In P. B. Sebring (Ed.), Charting school reform in Chicago: The students speak. Chicago: Consortium on Chicago School Research. 
Shriver, T. P., \& Weissberg, R. P. (August 16, 2005). No emotion left behind. New York Times Op-Ed.

Solomon, D., Watson, M. S., \& Battistich, V. A. (2002). Teaching and school effects on moral/prosocial development. In V. Richardson (Ed.), Handbook for research on teaching. Washington, DC: American Educational Research Association.

Solomon, D., Watson, M., \& Battistich, V. (2001). Teaching and schooling effects on moral/prosocial development. In V. Richardson (Ed.), Handbook of research on teaching (pp. 566-603). Washington, DC: American Educational Research Association.

Sternberg, R. (1998). Abilities are forms of developing expertise. Educational Researcher, 3, 22-35.

Strike, K. (1996). The moral responsibilities of educators. In J. Sikula, T. Buttery, \& E. Grifton (Eds.), Handbook of research on teacher education. (2nd ed., pp. 869-882). New York: Macmillan.

Tobler, N. S., Roona, M. R., Ochshorn, P., Marshall, D. G., Streke, A. V., \& Stackpole, K. M. (2000). School-based adolescent drug prevention programs: 1998 meta-analysis. The Journal of Primary Prevention. 20, 275-336.

Tom, A. (1984). Teaching as a moral craft. New York: Longman.

Vygotsky, L. S. (1935). The mental development of children in the process of learning. Oxford, England: Uchpedgiz.

Wahlberg, H. J., Zins, J. E., \& Weissberg, R. P. (2004). Recommendations and conclusions: Implications for practice, training, research, and policy. In J. E. Zins, R. P. Weissberg, M.C. Wang, \& H. J. Walberg (Eds.). Building academic success on social and emotional learning (pp. 209-226). New York: Teachers College Press.

Watson, M. (2003). Learning to trust. San Francisco: Jossey-Bass.

Watson, M., Battistich, V., \& Solomon, D. (1997). Enhancing students' social and ethical development in schools: An intervention program and its effects. International Journal of Educational Research, 27, 571-586.

Wentzel, K. R. (2002). Are effective teachers like good parents? Teaching styles and student adjustment in early adolescence. Child Development, 73, 287-301.

Wilson, D. B., Gottfredson, D. C., \& Najaka, S. S. (2001). School-based prevention of problem behaviors: A meta-analysis. Journal of Quantitative Psychology, 17, 247-171.

Youniss, J., \& Yates, M. (1997). Community service and social responsibility in youth. Chicago: University of Chicago Press.

Zimmerman, B. J. (1998). Academic studying and the development of personal skill: A self-regulatory perspective. Educational Psychologist, 33, 73-86.

Zimmerman, B. J. (2000). Attaining self regulation: A social cognitive perspective. In M. Boekaerts, P. Pintrich, \& M. Zeidner (Eds.), Handbook of selfregulation (pp. 13-39). New York: Academic Press.

Zins, J. E., Weissberg, R. P., Wang, M. C., \& Walberg, H. J. (2004). Building academic success on social and emotional learning. New York: Teachers College Press. 